Keywords:

Forest management

Forest optimization

Rural properties

Forest owners

Histórico:

Recebido 22/I2/2015

Aceito 06/06/2016

Palavras chave:

Manejo Florestal Otimização de floresta Propriedades Rurais Produtores florestais

Correspondência: rafaelrode@gmail.com
Rafael Rode', Helio Garcia Leite ${ }^{2}$, Daniel Henrique Breda Binoti², Carlos Antonio Álvares Soares Ribeiro², Agostinho Lopes Souza ${ }^{2}$, Diogo Nepomuceno Cosenza², Carlos Pedro Boechat ${ }^{2}$

\section{APPLYING CLASSICAL FOREST REGULATION METHODS TO SMALLHOLDINGS WITH COOPERATIVE CONSTRAINTS}

ABSTRACT: This study aims to assess the cooperative regulation process of forestry producers in comparison to the traditional individual regulation of properties. Twenty (20) forest properties are studied as examples of the development of three forest regulation scenarios: I) individual regulation, 2) group regulation, and 3) cooperative regulation. The Net Present Value (NPV) of each of the scenarios is optimized according to mathematical programming models and compared to a baseline scenario without forest regulation. According to the proposed cooperative regulation, properties had a proportion factor for annual net revenue distribution calculated from results of the baseline scenario. By comparing the NPV maximization results from scenarios I and 3 with the non-regulation scenario, the cost for individual regulation is on average $25 \%$, while being only II \% for cooperative regulation, that is, a $14 \%$ reduction in property regulation costs. Additionally, cooperative regulation had the advantage of dividing properties into fewer areas when compared to individual regulation.

\section{APLICAÇÃO DE MÉTODOS CLÁSSICOS DE REGULAÇÃo FLORESTAL EM PEQUENAS PROPRIEDADES COM USO DE RESTRIÇÕES COOPERATIVAS}

RESUMO: Este estudo teve como objetivo avaliar um processo de regulação cooperativa de produtores florestais, em comparar com o método de regulação clássico e individual das propriedades. Vinte propriedades florestais foram utilizadas 20 propriedades florestais como exemplo para elaboração de três cenários de regulação florestal: I) regulação individual, 2) regulação em grupo, e 3) regulação cooperativa. O Valor Presente Líquido (VPL) dos cenários foram otimizados a partir de modelos de programação matemática, e comparados com um cenário base, sem regulação florestal. Para a regulação cooperativa proposta, as propriedades tiveram um fator de proporção para distribuição da renda líquida anual, calculado a partir do resultado do cenário base. Comparando os resultados da maximização do VPL dos cenários I e 3 com o cenário sem regulação, o custo da regulação individual foi, em média, de $25 \%$, enquanto que para regulação cooperativa foi de II\%, ou seja, redução I4\% no custo da regulação das propriedades. A regulação cooperativa apresentou ainda a vantagem de menor divisão das áreas das propriedades quando comparado à regulação individual. 


\section{INTRODUCTION}

Companies owning large forest plantations annually increase their own planted areas or utilize outgrower schemes to meet the growing demand for industrial forest products (FERREIRA, 20I6; OLIVEIRA, 2006; RODE et al., 20I4). The growth of demand in the forestry sector attracts small rural producers and independent investors who begin to contribute to wood supply, influencing the local market.

However, the unawareness of a potential market, the inadequate management of plantation areas, and the lack of information on new techniques can render forestry activity economically unfeasible in small areas. According to Davis (1966), small proprietors might individually be unable to both handle their areas effectively and commercialize their products.

For Meins and Grouwels (20 I I), a major obstacle for many rural forest-dependent communities is that local stakeholders, including forest smallholders and indigenous people, are frequently not organized into partnerships for cooperative and unified action and advocacy, with many lacking the necessary skills to effectively engage in policy and funding processes. The result is that the parties with the most to gain are frequently excluded from important discussions, leaving their issues and particular needs unvoiced and unrepresented.

On the other hand, a new market may rise and attract new companies if controlled and quality wood supply increases within a region. Kittredge (2005) points out that small landowners are interested in developing cooperative plans and management strategies that scale beyond their individual property boundaries. According to the author, the "cooperative" concept is attractive to landowners due to many reasons. First, it represents a willingness to cooperate with other landowners at a landscape level in return for an opportunity to realize a host of tangible and intangible benefits. Next, many of the landowners, who are attracted to working with other like-minded owners on forestry projects, are sensitive to the conservation of natural resources, the principles that sustain ecological processes, and the flow of renewable natural resources. These landowners often pursue some form of green certification.

Landowners in a cooperative system might share an interest in helping the local economy by supplying wood products for both primary and secondary processing. They are able to search for new techniques and share information, equipment, and experiences in addition to leveraging their collective voice within the political arena (ASHTON et al., 20l I; STERN et al., 201 I; YOUNG; REICHENBACH, 1987).
At a local level, cooperatives have played a role in altering market arrangements and management philosophies, and otherwise challenging the status quo (RICKENBACH, 2009; RICKENBACH et al., 2005). Since cooperatives produce larger volumes of wood, prices for their forestry products are more easily negotiated. They can fulfill bigger market demands in addition to offering forestry multi-products (ASHTON et al., 2008; KITTREDGE, 2005; RAUCH, 2007).

In this sense, adequate forest planning in rural properties must be developed according to I) economic focus and 2) the intensity of their management practices (BLANCO et al., 20 I5). Managing areas based on a single cut cycle or by forest regulation can make a difference in enabling cooperative forest projects. According to Davis (1966), for a private landowner, it is worth achieving an approximate balance between revenues and expenses. Taxes for land ownership, capital, and other costs are paid annually. As per the regulation, financial control is facilitated to promote the balance between expenses and revenues.

The aim of a regulated forest is strongly linked to the concept of sustainable production, and, therefore, it leads to a balanced production during planning times (BUONGIORNO; GILLES, 2003; DAVIS, 1966; LEUCHNER, 1990) for stand, forest, or landscape level optimizations (KAYA et al., 2016).

Although the existence of discrepancies between the ideal cut time in an individually managed area and the optimum rotation in a regulated forest is recognized (NAUTIYAL, 1988), the former has been frequently used as an adequate substitute for the latter (BUONGIORNO; GILLES, 2003). Within small properties, in which revenues are not generated solely from forest production, classical regulation techniques can be employed, and even improved, if their landowners come together to enter more promising markets for forest products and subsequently increase their forest revenues.

This strategy can be also linked to the concept of group certifications for small producers. The group certification allows each member to receive benefits from larger markets without losing control of management procedures in their forest area, since the group certification gathers a large number of small areas in a single set (FOREST STEWARDSHIP COUNCIL - FSC, 2009).

Given the need for improving the management and commercialization of forest products in small rural properties, this study aims to assess a cooperative forestry regulation proposal on annual revenue achievement for rural producers and compare it to individual regulations in properties. 


\section{MATERIAL AND METHODS}

This study makes use of a case study involving 20 rural properties with the potential to produce eucalyptus wood. Data regarding age, size and productivity of the studied areas are presented in Table I.

TABLE I Information on plantation area, current age (years) and productivity at the age of 6 (Mean Annual Increment - $\mathrm{MAI}_{6}$ ), per rural property.

\begin{tabular}{cccc|cccc}
\hline Property & Age & $\begin{array}{c}\text { Area } \\
(\mathrm{ha})\end{array}$ & $\begin{array}{c}\mathrm{MAI}_{6} \\
\left(\mathrm{~m}^{3} \cdot \mathrm{ha}^{-1} \cdot \mathrm{y}^{\prime}\right)\end{array}$ & Property & Age $\begin{array}{c}\text { Area } \\
(\mathrm{ha})\end{array}$ & $\begin{array}{c}\mathrm{MAI}_{6} \\
\left(\mathrm{~m}^{3} \cdot \mathrm{ha}^{-1} \cdot \mathrm{y}^{\prime}\right)\end{array}$ \\
\hline 01 & 4 & 6.02 & 39.45 & $\mathrm{II}$ & 6 & 12.03 & 27.83 \\
02 & 4 & 21.32 & 27.50 & 12 & 5 & 5.24 & 48.78 \\
03 & 4 & 8.45 & 35.34 & 13 & 5 & 9.66 & 41.08 \\
04 & 4 & 5.36 & 38.62 & 14 & 5 & 18.18 & 44.52 \\
05 & 4 & 7.50 & 46.11 & 15 & 5 & 12.89 & 42.10 \\
06 & 5 & 34.65 & 45.82 & 16 & 5 & 4.91 & 44.69 \\
07 & 5 & 7.57 & 39.37 & 17 & 5 & 6.56 & 41.19 \\
08 & 6 & 5.62 & 42.63 & 18 & 6 & 19.50 & 48.25 \\
09 & 6 & 23.08 & 32.85 & 19 & 5 & 7.94 & 50.08 \\
10 & 5 & 6.80 & 49.82 & 20 & 6 & 6.29 & 34.26 \\
\hline
\end{tabular}

Total area: 229.57 hectares

The planting and management costs of the stands are shown in Table 2 . These costs are computed in an accumulated way up until the current age of the properties. Harvesting and transportation costs are not taken into account and the price of stumpage is assumed at USD $15.39 / \mathrm{m}^{3}$.

TABLE 2 Forestry costs per year for the first (seedling) and second (coppice) rotations.

\begin{tabular}{cccc}
\hline Description & Year & $\begin{array}{c}\text { Seedling } \\
\left(\text { USD } \cdot \mathrm{ha}^{-1}\right)\end{array}$ & $\begin{array}{c}\text { Coppicing } \\
\left(\text { USD } \cdot \mathrm{ha}^{-1}\right)\end{array}$ \\
\hline Supplies & 0 & 860.49 & 687.97 \\
Stand establishment & 0 & 465.84 & 192.55 \\
Maintenance & 1 & 106.48 & 106.48 \\
& 2 & 93.17 & 93.17 \\
Annual land cost & $0-\mathrm{n}$ & 53.24 & 53.24 \\
\hline
\end{tabular}

Eucalyptus plantations are managed under either a single-rotation or a coppice regime. An equation for timber production is adjusted for each outgrower using the seedling regime. Data from permanent plots measured in the stands are used. The production in the cut age was $10 \%$ less in the coppice regime than that from the same production in the seedling regime. The logistic model is used to estimate production: where $Y$ is the production $\left(\mathrm{m}^{3} \cdot \mathrm{ha}^{-1}\right), \beta i$ is the model coefficients, $l$ is the age in months, and $\varepsilon$ is the estimate error.

$$
Y=\frac{\beta}{1+\beta_{1} \mathrm{e}^{\beta_{2} I}}
$$

After defining costs, production, and incomes, different management prescriptions are elaborated for the properties, considering the following assumptions: a) 18 year planning horizon; b)Possibilities for age of cut between 4 and 8 years; c)Rural properties can be managed by seedling and coppice regimes or by alternating regimes in each rotation; d)Technical rotation age ( $R$ ) at 6 years; e)Transition time of 6 years (the minimum period to regulate the forest) and f)All sites have the same productivity.

Under single-rotation management, stands are clear-cut at harvest age and immediately reestablished by seedlings. In the coppice regime, stands harvested at the end of the first rotation are regenerated by coppicing and, at the end of the second rotation (coppice), are clear-cut and reestablished by seedlings.

The linear programing (LP) models are formulated in order to regulate forest production after generating all the possibilities or management prescriptions. It is necessary to define an objective function and constraints from different natures that control for the lack of resources. These models are commonly applied to forest planning approaches for continuous forest-based employment (LEE et al., 2005).

The objective function in this study deals with the maximization of Net Present Value (NPV) [2], using area limitation restrictions [3], annual cut area [4], and the minimum and maximum annual production limits [5]. In the function, $C_{i j}$ is the technological coefficient (net present value per hectare) of property $i$ in management option $j ; X_{i j k}$ is the decision variable regarding the size of the property's area (ha) $i$, indicated in management option $j$ in period $k$; $A_{i}$ is the area (ha) of property $i$; $R$ is the regulatory age; $V_{i j k}$ is the property's production $\left(\mathrm{m}^{3} \cdot \mathrm{ha}^{-1}\right) i$ in management option $j$ in period $k$; and $V_{k}$ is the limit for production by period $k$.

The objective function NPV [2] is calculated taking into consideration the cash flow within an 18-year planning horizon. Thus, the first six periods are defined as the transition time to regulate the stands, according to the defined rotation age. Therefore, at each planning year, $1 / 6$ of the stand area is cut.

Objective function:

$\operatorname{Max} N P V=\sum_{i=1}^{n} \sum_{j=1}^{m} C_{i j} x_{i j}$

Subject to:

Area limits

$\sum_{j=1}^{m} X_{i j}=A_{i}, \forall i$ 
$\sum_{j=1}^{m} X_{i j k}=A_{i} \cdot R-1, \forall k, i$

$\sum_{i=1}^{n} \sum_{j=1}^{m} v_{i j k} x_{i j} \lessgtr v_{k}, \forall k$

Due to some singularities found in the current study, the NPV calculation is comprised of different components: accumulated costs up to the current age, net present value from the six first periods, and the infinite net present value $\left(\mathrm{NPV}_{\infty}\right)$ from the sixth up to the eighteenth period. Thus, the technological coefficient $C_{i j}$ from the objective function that resulted from the sum of all costs and incomes updated for the planning zero (0) period is called the composite NPV[6]. In the composite NPV, $A C_{i j}$ is the accumulated cost in period $-p$ at 0 of property $i$ in management prescription $j$; $\mathrm{p}$ is the period or year of the first planting; $N P V_{t}$ is the Net Present Value of the transition period, with initial period 0 and final period 5; NPV $\infty$ is the infinite Net Present Value calculated from periods 6 to 17; $R_{k}$ is the incoming in period $\mathrm{k} ; C_{k}$ is the costs in period $k ; t$ is the total number of planning periods; and $r$ is the number of periods after the transition periods, accumulated costs [7], net present value [8], infinite net present value [9].

$$
\begin{aligned}
& C_{i j}=A C_{i j}+N P V t_{i j}+N P V \infty_{i j} \\
& A C=\sum_{k=-p}^{0} C_{k} \\
& N P V=\sum_{k=0}^{5} \frac{R_{k}-C_{k}}{(1+i)^{k}} \\
& N P V \infty=\frac{N P V(1+i)^{t}}{(1+i)^{r}-1}
\end{aligned}
$$

The calculation of the NPV $\infty$ in the technological coefficient $C_{i j}$ of the objective function is used as it allows a comparison among different management alternatives, since such a comparison is done over an infinite horizon. However, the transition period is considered separately from the NPV $\infty$, as this period only occurs once in the horizon planning, due to the adjustment of properties to obtain a regulated structure. In other words, after forest regulation, the transition period does not repeat itself in the cash flow.

Three regulation scenarios are elaborated in order to evaluate the cooperative regulation system proposal: a)Individual Regulation: within this scenario, areas (ha) from each rural property are regulated individually according to the classical regulation system per area by using the area[3] and regulation [4] constraint; b) Group
Regulation: within this scenario, regulation is performed with all the properties in one single LP model. In order to do so, it uses the model with the production balance restriction [5] included in the planning periods, in which the minimum limit is $9,500 \mathrm{~m}^{3}$.year-1 and the maximum limit is $1 \mathrm{I}, 500 \mathrm{~m}^{3}$.year ${ }^{-1}$. Such limits are arbitrarily defined and indicate a minimum production limit in all the periods when there is a feasible optimum solution; c) Cooperative regulation: The cooperative regulation proposal holds the following assumption: "forest producers from a certain region can regulate their wood production and manage it according to a single management system in which costs and total incomes are annually distributed among proprietors in a ratio that meets their individual maximum annual revenue."

In order to develop the cooperative regulation, three steps are necessary. First, the maximum revenue from each property is obtained by using the programing model with the objective function [2] and the area's mandatory restrictions [3], called the "baseline scenario." Second, the group regulation solution scenario is obtained in order to balance global production (i.e., all the properties) in all the planning periods and, consequently, to calculate the global net revenue by period with inclusion of equation [5] instead of equation [4]. Finally, the proportion factor calculation is performed on each property according to the outcomes from the first step, so that it can be multiplied by the global net revenue from the second step, thus calculating a weighting from this revenue in each property. The mentioned proportion factor (PF) is given as the following [10], where: $N P V_{i}$ is the composite net present value resulting from the baseline scenario solution (without regulation) for property $i$. With $P F_{i}$, it is expected that each proprietor receives income in proportion to their production potential.

$P F_{i}=\frac{N P V_{i}}{\sum_{i=1}^{n} N P V_{i}}$

The second stage refers to the control of annual production determined by equation 5 instead of equation 4. This change is necessary since the plantation areas do not have a set of trees at every age up to the cut age. In this way, the volume restriction in cooperative regulation will provide a minimum annual income to the owners.

Thus, it is expected that proprietors will receive revenues in all planning periods without the need of individual regulation. The optimum solution of the scenarios with regulation constraints is compared with the solution from the baseline scenario in order to note the features in each. 


\section{RESULTS AND DISCUSSION}

The result from the baseline scenario, describing the typical optimization behavior of areas and production without regulation constraint, is shown in Figure I.

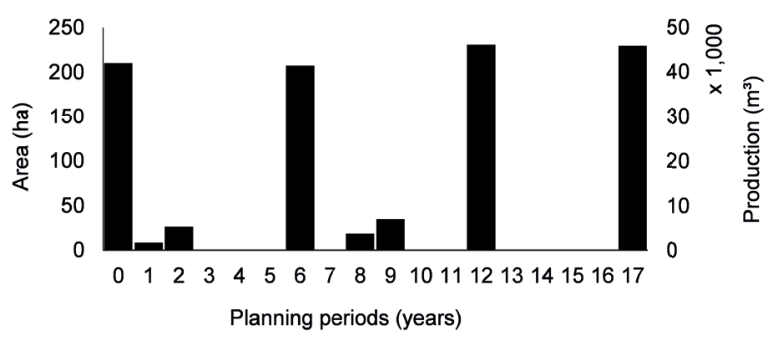

FIGURE I Cut area and total production of properties per planning year according to the baseline scenario.

Within such a scenario, areas are cut according to the maximum composite net present value criterion, controlling the area limitations of each property. It is observed (Figure I) that there are planning periods without wood production due to the fact that properties do not perform plantings in all age classes (Table I).

Based on this scenario, it is possible to compare, as observed in Figure 2, the behavior of cut areas and their respective productions when individual regulation restrictions are set (scenario I).

Individual regulation demands that each property must have 1/6 of its area cut annually in the 6-year rotation period. Such a requirement is well represented by the size of the total cut area in each planning year, according to the left graphic in Figure 2. Still, in this graphic, each bar represents a property and shows the annual cut areas from each property in ascending order. This is because the regulation constraints (3) per area are enforced by the individual property.

Additionally, the total annual production was more balanced compared to the baseline scenario and timber was harvested in all periods. Moreover, according to the right graphic in Figure 2, it is possible to clearly see the 6-years transition period (age 0-5) necessary to establish the project's regularization.

It is worth noting that in this transition, it was permitted to cut stands above 8 years, as established in the premises. Thus, a part of the areas with stands at 6 years will be cut in the fifth period when they are II years old, because they have greater added value, and in the next 6-year period, this part will be I year old as a regulated structure.

Another characteristic of this regulation observed on Figure 2 (bellow) is the difference in wood production between the 6-11 year period and the 12-17 year period. This is due to the coppice management being implemented after the first cut on the 0-5 year period, so that the second rotation (6-II year period) is slightly lower (10\%) than the third one (12-17 year period).

The imposition of regulation constraints in each property has a strong impact on the model's optimal solution when compared to the scenario without regulation. Table 3 presents the composite NPV optimal solution for each property in ascending order, and the overall results for the baseline and individual regulation scenarios.

The overall impact of individual regulation was a $25 \%$ reduction on NPV in comparison with the baseline scenario; properties I and 5 were the least affected (20\%), while property II was the most affected (43\%). The calculation for the composite NPV allows for the comparison of the two scenarios, since cash flow was not taken to the infinite horizon on the transition period. Thus, it is possible to confirm that higher revenue is achieved when management is executed using clear cutting rotation, according to Nautiyal (1988).

There is a lengthy discussion about the advantages and disadvantages of wood production managed upon regulation regimes. However, it is worth highlighting the advantages gained when it is applied to small properties. The annual revenue can have a greater impact on the farmer's family income. Moreover, a regulated forest strongly helps to conserve the environment, since soil is only used partially, reducing nutrient losses due to erosion, and allows the more effective use of residues to reduce the visual impact on the landscape (BETTINGER, 2009; DAVIS, 1966; DAVIS et al., 200 I; LEUSCHNER, 1990).
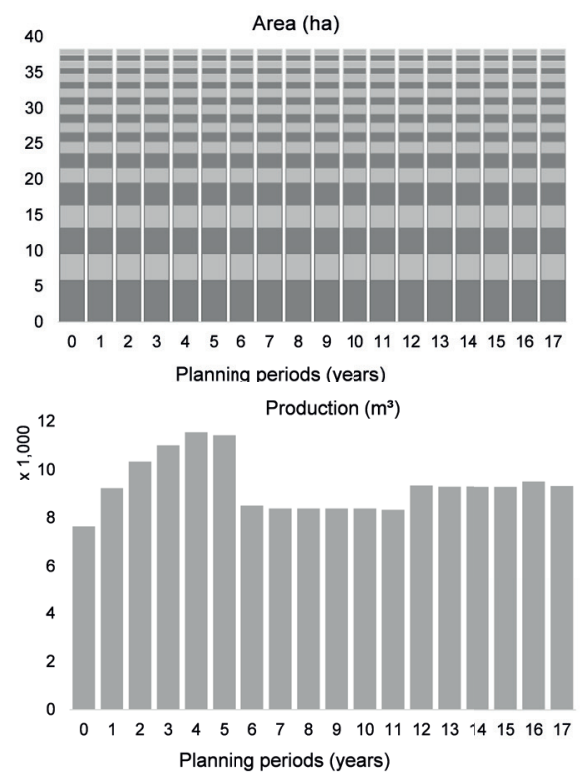

FIGURE 2 Cut area and total production of properties per year of planning according to the individual regulation scenario. 
TABLE 3 Results from the global composite NPV (USD) of the baseline scenario (without regulation), scenario I (individual regulation), and the regulation cost (absolute and percentage) from the study's 20 properties.

\begin{tabular}{|c|c|c|c|c|}
\hline Properties & $\begin{array}{l}\text { Without } \\
\text { regulation }\end{array}$ & $\begin{array}{l}\text { Individual } \\
\text { regulation }\end{array}$ & Cost & $\%$ \\
\hline I & $52,167.03$ & $41,689.86$ & $10,477.17$ & 20.08 \\
\hline 2 & $73,010.26$ & $44,674.22$ & $28,336.04$ & 38.81 \\
\hline 3 & $63,694.30$ & $44,901.06$ & $18,793.24$ & 29.51 \\
\hline 4 & $44,326.34$ & $35,395.60$ & $8,930.74$ & 20.15 \\
\hline 5 & $90,267.07$ & $72,|4| .84$ & $18,125.23$ & 20.08 \\
\hline 6 & $444,834.56$ & $342,043.23$ & $|02,79| .33$ & 23.11 \\
\hline 7 & 7I,277.68 & $54,637.14$ & $16,640.54$ & 23.35 \\
\hline 8 & $79,085.56$ & $58,869.06$ & $20,216.51$ & 25.56 \\
\hline 9 & $163,465.39$ & II7,975.67 & 45,489.7I & 27.83 \\
\hline 10 & $101,952.24$ & $81,011.49$ & $20,940.76$ & 20.54 \\
\hline II & $46,348.07$ & $26,548.08$ & $19,799.99$ & 42.72 \\
\hline 12 & $75,283.05$ & $58,183.22$ & $17,099.83$ & 22.71 \\
\hline 13 & $99,504.10$ & $76,652.68$ & 22,85 I. 42 & 22.97 \\
\hline 14 & $220,6|4.0|$ & $168,660.72$ & $51,953.29$ & 23.55 \\
\hline 15 & $139,767.54$ & $107,962.23$ & $31,805.31$ & 22.76 \\
\hline 16 & $60,082.44$ & $45,959.82$ & $14,122.62$ & 23.51 \\
\hline 17 & $67,996.63$ & $52,456.30$ & $15,540.32$ & 22.85 \\
\hline 18 & $291,838.94$ & $213,570.94$ & $78,268.00$ & 26.82 \\
\hline 19 & $119,852.26$ & $92,082.80$ & $27,769.46$ & 23.17 \\
\hline 20 & $40,182.14$ & $31,853.44$ & $8,328.70$ & 20.73 \\
\hline Total & $2,345,549.6 \mathrm{I}$ & I,767,269.40 & $578,280.21$ & 24.65 \\
\hline
\end{tabular}

Such environmental contributions are related to the regulation cost, a fact that can be understood as a necessary compensation as payment for environment services to the proprietor. For instance, to property I, it could be paid as a lump sum of USD 10,477.I7 to the proprietor, so that he could regulate his forest and keep it regulated from this point on.

Owing to the difficulties involved in individual regulation with traditional regulation per area, it may be more interesting to use demand balance restrictions or even revenue restrictions (e.g. equation 4) in the programing models.

The optimization results of scenario 2 with group regulation are present in Figure 3 for area distribution and total production.

The balance in production is observed throughout the planning years, due to the minimum production restriction of $9.500 \mathrm{~m}^{3}$.year-I. However, cut areas present variations since each property has a different production. As there are no regulation restrictions per area in this
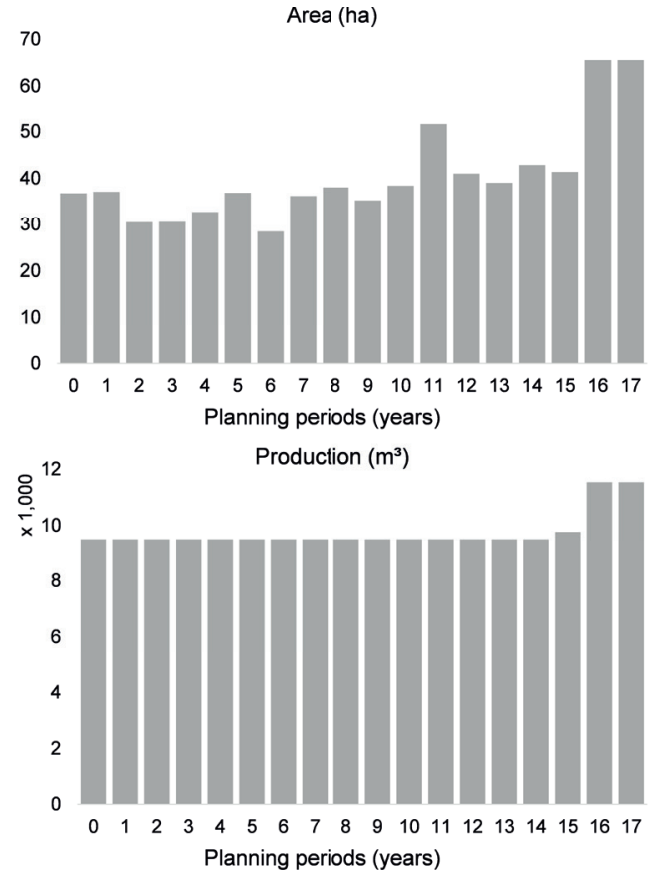

FIGURE 3 Cut area and the properties' total production during the planning periods for the group regulation scenario.

model, there are differences on cut areas throughout the years, thus leading to increases in the last two periods. Such increases are explained by the minimum cutting age allowed (4 years). The optimization tries to maximize NPV by choosing a prescription that allows cuts during a younger age for the last rotation, because it generates one additional income. The opposite would occur if the forest areas were left without a cut.

This balance was observed in production due to the division of some properties by the linear optimization. This was expected since there are currently no planted areas for all the age classes (I to 6 years). However, such a division is smaller when compared to the number of individual regulation scenario divisions. Moreover, in scenario 2, the particular property does not necessarily have an annual revenue because the periodic production constraints in the model (equation 4) were imposed by only adding up the volume of wood produced in each year.

In the case where incomes are provided to the properties individually, a new annual production minimum limit could be inserted in each one of them. However, the outcome would be quite similar to that already presented in the individual regulation scenario, since there is no site variation in the properties, but only among them.

Another method that can be used to achieve these incomes from the group regulation results could be to award a proportional revenue according to their 
participation or contribution to the global revenue. According to described methodology, this proportion may be calculated with the NPV ratio of the property by the global NPV obtained from the baseline scenario result.

In order to visualize the difference between scenarios 2 (group regulation) and 3 (cooperative regulation), the net revenue from the 20 properties on horizon planning is presented in Figure 4.

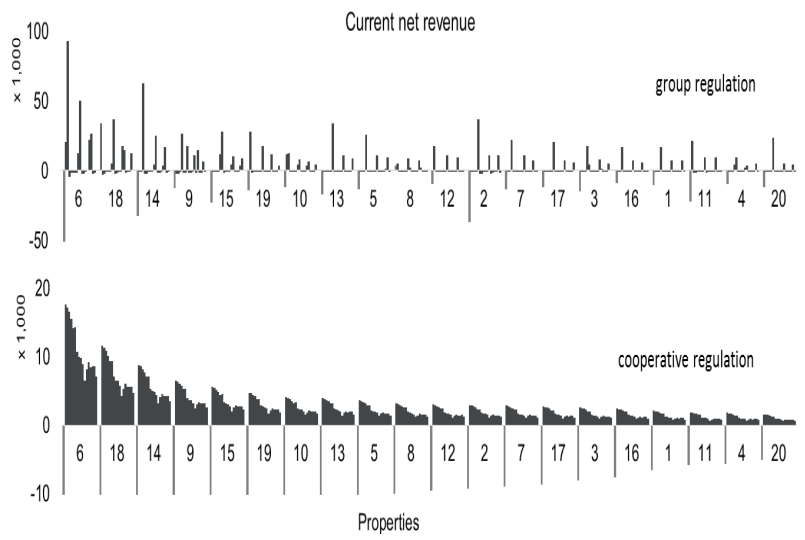

FIGURE 4 Current net revenue in scenarios 2 (group regulation) and 3 (cooperative regulation) from all twenty properties grouped per planning year.

According to the group regulation (Figure 4), incomes are generated in some periods, whereas in others only costs are present. When the proportion factor from each property is multiplied by the total net revenue from scenario 2 , regulation becomes cooperative (Figure 4). Thus, it is observed that properties generate revenue in every year, except for period 0 , in which the net revenue is negative due to the annual accumulated costs from the first planting procedure until this period. Period 0 can be identified in the figures by the negative value bars that divide the properties' identifications in the horizontal axis.

It is still observed that, in scenario 3, net revenue varies among the planning periods since regulation is based on the gross revenue. If it were required, the net revenue could be used and the graphics would be more equitable, but it would most likely show larger regulation costs.

The revenue behavior in the periods is comparable in all the properties, showing only a difference in size, since participation is proportional to the properties' total revenue. It is worth remembering that as properties have the same net revenue behavior (i.e., in some periods some proprietors earn more revenues and others earn less), total production also follows this variation.

In order to better observe differences in scenarios without regulation, with group regulation, and with cooperative regulation, Table 4 presents the total composite NPV optimization and per property results from the baseline scenario in ascending order.

Group and cooperative regulation scenarios are equal for the optimum solution value (NPV) because the proportion factor is applied to the total regular net revenue from the group regulation. Thus, NPV and the annual net revenue are equal in both scenarios.

As already seen in Table 3, the mean regulation cost in scenario I (individual) had a range of $25 \%$ in comparison to the baseline scenario (without regulation). The cost was lower when it was applied to the group regulation (i.e., almost 15\%) (Table 4). However, this is the cost for the total NPV from the optimization of the scenarios (baseline and scenario 2). If the cost per property is observed, the percentage difference in some cases doubles the total (>30\%) and, in other properties, for example, 17, 13 and 15, the differences were negative, thus indicating that the model favors some areas over others. This occurs because, in the group regulation, some properties are cut during times that are not ideal for fulfilling the regular demands set by global production restrictions. Therefore, it becomes apparent that the group regulation, as it was applied, must not be accepted for controlling production.

TABLE 4 Global composite NPV results (USD) from scenarios without regulation (baseline), with group regulation (2) and with cooperative regulation (3) and the percentage differences in regulation costs for the 20 properties in the study.

\begin{tabular}{|c|c|c|c|c|c|}
\hline \multirow{3}{*}{ Properties } & \multirow{3}{*}{$\begin{array}{c}\begin{array}{c}\text { Baseline } \\
\text { scenario }\end{array} \\
\text { Without } \\
\text { regulation }\end{array}$} & \multirow{3}{*}{$\begin{array}{c}\text { Scenario } 2 \\
\begin{array}{c}\text { Group } \\
\text { regulation }\end{array}\end{array}$} & \multirow{3}{*}{$\begin{array}{c}\text { Scenario } 3 \\
\begin{array}{c}\text { Cooperative } \\
\text { regulation }\end{array}\end{array}$} & \multicolumn{2}{|c|}{ Difference (\%) } \\
\hline & & & & $\begin{array}{l}\text { Baseline } \\
\text { Scen. } x\end{array}$ & $\begin{array}{l}\text { Baseline } \\
\text { Scen. } x\end{array}$ \\
\hline & & & & Scen.2 & Scen. 3 \\
\hline 1 & $52,167.03$ & $4 I, I 74.87$ & $44,478.03$ & 21.07 & 14.74 \\
\hline 2 & $73,010.26$ & $26,010.66$ & $62,249.15$ & 64.37 & 14.74 \\
\hline 3 & $63,694.30$ & $43,099.92$ & $54,306.28$ & 32.33 & 14.74 \\
\hline 4 & $44,326.34$ & $30,074.79$ & $37,793.00$ & 32.15 & 14.74 \\
\hline 5 & $90,267.07$ & $69,451.58$ & $76,962.44$ & 23.06 & 14.74 \\
\hline 6 & $444,834.56$ & $363,288.28$ & $379,269.60$ & 18.33 & 14.74 \\
\hline 7 & $71,277.68$ & $51,977.15$ & $60,771.93$ & 27.08 & 14.74 \\
\hline 8 & $79,085.56$ & $67,587.09$ & $67,429.00$ & 14.54 & 14.74 \\
\hline 9 & $163,465.39$ & $134,032.28$ & $139,371.93$ & 18.01 & 14.74 \\
\hline 10 & $101,952.24$ & $88,441.50$ & $86,925.32$ & 13.25 & 14.74 \\
\hline II & $46,348.07$ & $35,280.90$ & $39,516.75$ & 23.88 & 14.74 \\
\hline 12 & $75,283.05$ & $64,736.59$ & $64,186.95$ & 14.01 & 14.74 \\
\hline 13 & $99,504.10$ & $137,0 \mid 4.03$ & $84,838.01$ & -37.70 & 14.74 \\
\hline 14 & $220,6 \mid 4.01$ & $160,429.06$ & $188,097.32$ & 27.28 & 14.74 \\
\hline 15 & $139,767.54$ & $145,992.13$ & $119,166.95$ & -4.45 & 14.74 \\
\hline 16 & $60,082.44$ & $4 \mathrm{I}, 456.08$ & $51,226.78$ & 31.00 & 14.74 \\
\hline 17 & $67,996.63$ & $85,651.01$ & $57,974.49$ & -25.96 & 14.74 \\
\hline 18 & $291,838.94$ & $280,827.65$ & $248,824.29$ & 3.77 & 14.74 \\
\hline 19 & $119,852.26$ & $105,379.78$ & $102,187.02$ & 12.08 & 14.74 \\
\hline 20 & $40,182.14$ & $27,929.54$ & $34,259.63$ & 30.49 & 14.74 \\
\hline Total & $2,345,549.61$ & $1,999,834.89$ & $1,999,834.89$ & 14.74 & \\
\hline
\end{tabular}


However, when the proportion factor is applied, the percentage differences between the baseline and the cooperative regulation scenarios are equal for all properties (14.74\%), meaning that revenues and costs are shared in the same proportion among landowners.

It is also observed in Table 4 that the properties 17,13 and 15 presented the highest income in the group regulation, when compared to the unregulated (baseline) scenario. This result is a consequence of the optimization model, in which there are no individual control productions, as observed in scenario 2 . In practice, this means that some owners hold advantages over the group. It is assumed that these properties had less individual regulation than the baseline scenario (Table 3).

Thus, the cooperative regulation is more helpful to proprietors since it reduced regulation cost by approximately $10 \%$. Such a response may encourage rural producers to join a cooperative system. According to Vokoun et al. (20l0), landowners will set a cooperation agreement if the benefits are greater than those received if they kept private control of the forestry stocks in their lands.

Another aspect that can be discussed in a cooperative process considers initial forestry costs. Together, proprietors can spend inputs with lower market value than those acquired individually. Thereby they can reduce, for instance, planting and management costs as well as enhance economic return.

Using this fact, a new scenario is built using costs (Table I) that had been reduced by 10\%, with the exception of the annual land cost. The composite NPV in the optimum solution is reduced from USD 2,345,549.6 I in the individual scenario to USD I,999,834.89 in the new cooperative regulation one. This is equivalent to a regulation cost of $8.65 \%$, which is approximately $6 \%$ lower than the previous regulation cost (I4.74\%).

According to the results, regulation in small rural properties in a cooperative system can bring about economic benefits through regular revenue and forestry management benefits, since constant interventions are not needed in achieving this revenue. Furthermore, the cooperative regulation can be further studied according to the group certification process (BASSO et al., 20I I; FSC, 2009) and its application feasibility can also be evaluated.

This system can also be studied in an agroforestry system, where many landowners can join in a cooperative, which could only be applied to the forestry component or the system as a whole. Agroforestry systems represent a major form of small-scale tree planting, where trees are grown in purposeful combinations with agricultural crops and/or livestock in order to take advantage of treecrop interactions This system enhances crop production, diversifies farm output, stabilizes or improves soils, and ameliorates harsh environmental conditions (LONG; NAIR, 1999).

\section{CONCLUSION}

The cooperative regulation for smallholdings is a more favorable economical alternative in managing wood production than individual regulation.

Forest producers must first organize themselves into a cooperative and then apply this regulation method. Thus, in each period the total income can be distributed proportionally among them.

The cooperative regulation method has the advantage of subdividing areas into a fewer number of properties to meet the production demand when compared to the individual regulation method.

\section{REFERENCES}

ASHTON, S. F.; HULL, B.; VISSER, R. M.; MONROE, M. $C$. Forest management in the interface: forest cooperatives. FOR I76 University of Florida, IFAS Extension, Gainsville. 20I I. Available at: https://edis.ifas.ufl. edu/fr244. Accessed in: 08 setembro 2015.

BASSO, V. M.; JACOVINE, L. A. G; ALVES, R. R.; VIEIRA, S. L. P.; SILVA, F. L. Certificação florestal em grupo no Brasil. Floresta e Ambiente, v. 18, n. 2, p. 160-170, 201 I.

BETTINGER, P.; BOSTON, K.; SIRY, J. P.; GREBNER, D. L. Forest management and planning. Elsevier: Academic Press, 2009. $331 \mathrm{p}$.

BLANCO, V.; BROWN, C.; ROUNSEVELL, M. Characterising forest owners through their objectives, attributes and management strategies. European Journal of Forest Research. v. 134, n. 6, p. 949-II54, 2015.

BUONGIORNO, J.; GILLESS, J. K. Decision methods for forest resource and management. Elsevier: Academic Press, 2003. 429p.

DAVIS, K. P. Forest management: regulation and valuation. 2ed. McGraw-Hill: New York, 1966. 519p.

DAVIS, L. S.; JOHNSON, K. N.; BETTINGER, P.; HOWARD, T. E. Forest management: to sustain ecological, economic, and social values. 4ed. McGraw-HillWaveland Press: Illinois, 200I. 790p.

FERREIRA, M. A. Planejamento otimizado da produção de madeira no fomento florestal. 68 f. 2016.Dissertação (mestrado em Engenharia Florestal) - Universidade Federal de Lavras, Lavras - MG, 2016. 
KAYA, A.; BETTINGER, P.; BOSTON, K.; AKBULUT, R.; UCAR, Z.; SIRY, J.; MERRY, K.; CIESZEWSKI, C. Optimisation in forest management. Current Forestry Reports, v.2, p.I-I7, 2016.

KITTREDGE, D. B. The cooperation of private forest owners on scales larger than one individual property: international examples and potential application in the United States. Forest Policy and Economics, v.7, p. 67I-688, 2005.

LEUSCHNER, W. A. Forest regulation, harvest scheduling, and planning Techniques. Wiley-Interscience, 1990. 28I p.

LEE, W. K.; BIGINS, G. S.; VON GADOW, K.; BYUN, W. K. A forest planning model for continuous employment in a forested village with primarily young stands in Korea. New Forests, v.29, n. I, p. I5-32, 2005.

LONG, A. J.; NAIR, P. K. R. Trees outside forests: agro-, community, and urban forestry. New Forests, v. I7, n. I-3, p. 145-174, 1999.

MEINS, L. S.; GROUWELS, S. Growing forest partnerships in Guatemala. In: 20II IUFRO Small-scale Forestry Conference: Synergies and conflicts in social, Ecological and economic interactions, Freiburg, p. 127-132, 2011.

NAUTIYAL, J. C.; Forest economics: Principles and applications. Canadian Scholar's Press, 1988. 580p.

FSC - Forest Stewardship Council. FSC standard for group entities in forest management groups. Document FSCSTD-30-005 (VI-0) EN, 2009. Available at: https://ic.fsc.org/ group-certification.3 12.htm. Accessed in: 17 march 2016.
RAUCH, P. SWOT analyses and SWOT strategy formulation for forest owner cooperation in Austria. European Journal of Forest Research, v. I26, p. 4I3-420, 2007.

RICKENBACH, M.; ZEULI, K, STURGESS-CLEEK, E. Despite failure: the emergence of "new" forest owners in private forest policy in Wisconsin, USA. Scandinavian Journal of Forest Research, v. 20, p. 503-513, 2005.

RICKENBACH, M. Serving members and reaching others: The performance and social networks of a landowner cooperative. Forest Policy and Economics, v. II, p. 593599, 2009.

STERN, T.; SCHWARZBAUER, P.; HUBER, W.; WEISS, G.; AGgeStAM, F;; WIPPEL, B.; PETEREIT, A.; NAVARRO, P.; RODRIGUEZ, J.; BOSTRÖM, C.; ROBERT, M. Market supply of wood from areas with fragmented forestownership structures - a European case study approach. In: 20 I I IUFRO Small-scale forestry: Synergies and Conflicts in Social, Ecological and Economic Interactions, Freiburg, p. $91-100,2011$.

VOKOUN, M.; AMACHER, G. S.; SULIVAN. J.; WEAR, D. Examining incentives for adjacent non-industrial private forest landowners to cooperate. Forest Policy and Economics, v. 12, p. 104-II0, 2010.

YOUNG, R. A.; REICHENBACH, M. R. Factors influencing the timber harvest intentions of non-industrial private forest owners. Forest Science., v. 33, n. 2, p. 38I-393, 1987. 
